\title{
The Effect of Facilities and Motivation on Learning Outcomes of High School Students in Gelumbang, Indonesia
}

\author{
Dedy Hariyanto \\ SMA PGRI Gelumbang \\ e-mail: dedyislive@gmail.com \\ Yasir Arafat \\ Universitas PGRI Palembang \\ e-mail: yasirarafat@univpgri-palembang.ac.id \\ Dessy Wardiah \\ Universitas PGRI Palembang \\ e-mail: dessywardiah77@gmail.com \\ Article History: Received on 1 July 2021, Revised on 27 July 2021 \\ Published on 30 July 2021
}

\begin{abstract}
Qualified teachers play a very important role in improving learning process in schools. Teachers who are able to use facilities as learning resources will have a positive impact on student success at school. The more complete facilities in the school, the more motivated students will be in the learning process. The purpose of this study was to determine the effect of facilities and motivation on student learning outcomes at SMA PGRI Gelumbang. The type of research conducted was quantitative which analyze the questionnaire data, which is then analyzed using SPSS For Windows. The results of the study indicate that there is an influence of learning facilities and motivation together either simultaneously or partially on student learning outcomes in high school. This paper contibutes to more focus on facilities and motivation to have quality learning outcomes.
\end{abstract}

Keywords: Facilities, Motivation, Learning Outcome.

\section{A. Introduction}

Basically the learning process is characterized by changes in overall behavior both in terms of cognitive, affective, and psychomotor. In general, student learning outcomes are influenced by internal factors that exist within students and external factors are outside of students (Hamalik, 2012). Yamin (2012) said that to get good learning outcomes, it is necessary to have a facility that can help encourage students to achieve maximum achievement. In law number 19 of 2005 concerning National Education Standards contained eight standards including the standard of facilities and infrastructure in article 42 paragraph (1) every education unit is required to have facilities which include furniture, educational equipment, educational media, books and other sources, consumables, as well as other equipment needed to support an orderly and continuous learning process. Paragraph (2) that each education unit is required to have infrastructure which includes land, rooms, classrooms, education unit leadership rooms, educator rooms, administration rooms, library rooms, laboratory rooms, workshop rooms, production unit rooms, canteen rooms, power installations. and services, places to exercise, places of worship, places to play, places to be creative, and other places needed to support an orderly and continuous learning process. Law number 20 of 2003 in Article 45 paragraph 1 of the success 
Volume 2 (1) 2021

E-ISSN: 2723-6919 P-ISSN:2746-0827

or failure of students in learning is thought to be determined by how much effort they make to learn and also their attention to the factors that support and hinder the process and learning outcomes.

Learning facilities and infrastructure have a very large function in relation to the educational process. Its existence is absolutely necessary in the educational process, so that learning facilities and infrastructure are included in the components that must exist and be fulfilled in carrying out the educational process. Without these facilities and infrastructure, the educational process will experience very serious difficulties, it can even thwart an educational process. An incident that must be avoided by all parties involved in education (Djamarah, 2011).

There are only two Senior High Schools (SMA) in Gelumbang District, Muara Enim Regency, namely SMA PGRI Gelumbang and SMA Negeri 1 Gelumbang. Initial information obtained from the head of SMA PGRI Gelumbang that the school strives to provide the best for the success of students in the learning process, including providing learning facilities, such as sports equipment, and art studio activities as well as teachers trying to motivate students to achieve achievement. student learning itself, such as providing additional lessons, asking students to find learning resources by utilizing library facilities or looking for learning resources through websites, training students in the arts and sports fields.

Furthermore, data from SMA Negeri 1 Gelumbang, obtained information that the infrastructure owned to support the teaching and learning process at SMA Negeri 1 Gelumbang includes, local learning as many as 27 local study rooms, Library Room, Physics Laboratory Room, Biology Laboratory Room, Laboratory Room, Room BP, UKS Room, Student Council Room, places of worship, Principal's Room, Deputy Principal's Room, Teacher's Room, several toilets, school fields, sports facilities such as volleyball, badminton, football, table tennis, musical instruments for the arts such as drums, guitar, sound system, ketipung, organ, flute, harmonica, and piano. In the given learning process, there are teachers who deliver learning materials that are not linear with their education, while the learning motivation given is not all going well. In other words, the teacher provides learning motivation but students are less enthusiastic about accepting it, on the contrary, the student's motivation to learn is good, the teacher does not provide the motivation to learn (Yunita et al, 2020).

The reason for the researcher to examine the related facilities and motivation on learning outcomes is to find out whether the existing facilities in the high school and the teacher's efforts to provide student learning motivation are able to change the learning outcomes of high school students in a better direction, and whether the existing facilities make a good contribution (Maryati et al, 2021). Student learning outcomes or learning motivation given by the teacher is able to improve student learning outcomes. Besides that, the researcher saw that there were no other researchers who did research with the same title in SMA in Gelumbang District. This paper will have contribution to principal in improving the learning outcome with good facilities and student's motivation.

\section{B. Literature Review}

Learning outcomes are the most important part in learning, according to Suryabrata (2014), a result that can be achieved by someone who learns within a certain time interval can be said to be learning outcomes. Student learning outcomes in schools are shown in the form of assessments, either at the end of each material or within a certain period of time. 
Volume 2 (1) 2021

E-ISSN: 2723-6919 P-ISSN:2746-0827

In line with this opinion, Haryati (2011) argues that the assessment of student learning outcomes carried out by teachers is in addition to monitoring the process, progress and development of student learning outcomes, as well as feedback to teachers in order to improve the planning and process of learning programs that apply the approach mastery learning and in the assessment process applying a continuous assessment system involving three domains, namely cognitive, psychomotor, and affective. Furthermore, Mulyasa (2012) states, a learning can be declared successful if all or at least most (75\%) students are actively involved, both physically, mentally and socially in the learning process.

The results achieved cannot be separated from the relationship with the circumstances and background of the individual concerned, the situation, conditions, and implementation processes and various facilities that support teaching and learning activities. The results obtained from the process of implementing teaching and learning activities for students are called learning outcomes (Slameto, 2014). Meanwhile, according to Hasibuan (2010), learning outcomes are abilities that are possessed after he receives his learning experience. The learning process has goals that have been set previously and to be achieved from the teaching and learning process that has been implemented. Learning outcomes are the results achieved by a person when doing certain tasks or activities. Learning outcomes are mastery of knowledge or skills developed by subjects which are usually indicated by test scores or scores given by the teacher (Roestiyah, 2018).

Based on the description above, the researcher can conclude that learning outcomes are a complex process that can occur in every individual because of interactions with the environment that produce a change in behavior to achieve goals as a result of his own experience in order to improve personal abilities or competencies.

According to Slameto (2014), the factors that influence learning are of many types, but can be classified into only two groups, namely internal factors and external factors. Internal factors are factors that exist within the individual who is studying, for example, when the daily test takes place, students in a sick condition are unable to answer the questions given, so that the daily test results are small, while external factors are factors that exist outside the individual. For example, students who like to leave class hours because of the influence of their friends. Meanwhile, according to Syah (2011), globally explaining the factors that influence student learning are divided into three kinds, internal factors, external factors, and factors of learning approach.

Furthermore, Hamalik (2012) explains that the factors that influence learning are 1) internal factors which include: a) physical: health, disability, b) psychological factors: intelligence, attention, interest, talent, motivation, maturity and readiness; 2) external factors which include social environmental factors, namely: teachers, administrative staff, classmates, neighbors and the community, and non-social environmental factors, namely the school building and its location, housing, learning tools, weather conditions and time (Astuti et al, 2020).

Roestiyah (2018) explains that the factors that influence learning are: (1) The existence of a curious nature who wants to investigate the wider world; (2) The existence of a creative nature that exists in humans and the desire to always progress; (3) The desire to get sympathy from parents, teachers and friends; (4) There is a desire to improve past failures with new businesses, both with cooperatives and with competition; (5) The desire to get a sense of security when mastering the lesson; and (6) There is a reward or punishment as the end of learning. Furthermore, Purwanto (2015) explains that the factors that influence learning are: 1) student 
intelligence, 2) student attitudes, 3) student talents, 4) student interests, and 5) students' selfmotivation (Astuti et al, 2020) (Ibrahim et al, 2020).

Based on the description above, it can be concluded that the factors that influence student learning are internal factors and external factors.

Facilities and infrastructure are etymologically different, but both have a very important relationship as a means of supporting the success of a process carried out. Thus, a process of activities that will be carried out will not be able to achieve the expected results according to the plan, if the facilities and infrastructure are not available (Hamalik, 2012).

In general, what is meant by means is a set of tools used for an activity, the tool can be in the form of a main tool or a tool that helps the activity process, so that the objectives of the activity can be achieved. Actually, the facility does not only include a set of tools or goods, but can also be a place or room for the activity process (Aunurrahman, 2014).

Facilities are objects both movable and immovable that can be used as tools in carrying out tasks, such as cars, computers, pens, paper, printer ink, buildings, rooms, and others (Triwiyanto, 2015). School facilities include all items and equipment used during the educational process at school. School infrastructure is all components that indirectly support the teaching and learning process or all existing facilities prior to the existence of facilities in schools such as: roads leading to schools, yards, and others (Musfiqon, 2016).

Furthermore, Matin and Nurhattati (2016) stated that facilities are tools that are the main support for the implementation of a process of teaching and learning activities. This has been explained in Government Regulation Number 32 of 2013, Chapter II Article 2 states that the National Education Standard Environment, one of which is the standard of facilities and infrastructure. The paragraph of Article 24 of the PP states as follows: 1) Every educational unit is required to have facilities that include furniture, educational equipment, educational media, books, and other learning resources, consumables, and other equipment needed to support an orderly learning process. and sustainable; 2). Each education unit is required to have infrastructure which includes land, classrooms, education unit leadership room, educator room, administration room, library room, laboratory room, workshop room, production unit room, canteen room, power and service installation, exercise area, places of worship, places to play, places to be creative, and other spaces or places needed to support an orderly and continuous learning process.

Based on the description above, the researcher can conclude that the facility is a tool as a complement in the learning process carried out by both teachers and students as a support in the learning activities. Karwono (2017) explains that in terms of its function or role in the implementation of the teaching and learning process, educational facilities are divided into two types, namely 1) learning tools such as books in the library, teacher handbooks, textbooks for students, dictionaries, props; 2) practical tools, such as sports equipment, arts, laboratory equipment, and so on; 3) stationery, such as blackboards, notebooks, pens, pencils, chalk, markers, computers, and so on; 4) educational media, which can be used for learning process activities that encourage students to think, willingness to learn in order to achieve goals.

Furthermore, Pribadi (2015) explained that the main functions of facilities and infrastructure are basically: 1) creating student comfort in learning; 2) create satisfaction, facilitate learning activities; 3) accelerate the process of learning activities; 4) increase learning productivity; 5) 
Volume 2 (1) 2021

E-ISSN: 2723-6919 P-ISSN:2746-0827

the quality of the results achieved is better. According to Sanjaya (2010), learning facilities are everything that supports the smooth learning process. School learning facilities and infrastructure are very important in the learning process to support the learning process. With various kinds of school learning facilities and infrastructure available and utilization that can support learning activities, it will certainly help students in learning both at home and at school. Roestiyah (2018) explains that learning facilities are learning tools needed in the learning process so that the achievement of learning objectives can run smoothly, regularly, effectively and efficiently. Judging from the function, learning facilities are divided into learning tools and teaching aids.

Based on the description above, the researcher can conclude that the function of learning facilities is to support student learning in increasing productivity and quality of learning outcomes achieved, being able to create comfort in student learning, facilitating student learning activities, and accelerating the learning process. According to Musfiqon (2016) the facilities and infrastructure that must be owned by schools to support teaching and learning activities are as follows: 1) school buildings, 2) local learning, 3) teacher rooms, 4) laboratory rooms, 5) places of worship, 6) rooms library, 7) counselor room, 8) UKS room, 9) school field, 10) sports equipment, 11) art tools, 12) books to support student learning, learning media and so on related to student learning interests.

Furthermore, Daryanto (2017) argues that the facilities that must be owned by educational institutions are generally called facilities consisting of learning facilities and infrastructure, that learning facilities are direct tools to achieve educational goals, for example learning guide books, stationery, notebooks, media learning and others, while infrastructure is an indirect tool to achieve educational goals, for example rooms, libraries, laboratories and so on. Gunawan (2016) suggests that school facilities and infrastructure are one of the supporting factors in achieving the success of the teaching and learning process in schools. Of course, this can be achieved if the availability of adequate facilities and infrastructure is accompanied by optimal management, including: 1) study room, 2) educational activity management room, 3) worship room, 4) UKS room, 5) laboratory room, 6) room counseling, 7) learning activity equipment warehouse, 8) activity support field, and other supporting facilities.

Motivation comes from the word motive, namely the power contained in the individual, which causes the individual to act or do (Darmiati et al, 2020). There are two kinds of motives, namely intrinsic motives and extrinsic motives. Intrinsic motives, the emergence does not require stimulation from outside because it already exists within the individual himself, that is according to or in line with his needs. While extrinsic motives arise due to stimuli from outside the individual. Learning is Learning is an activity to make someone learn. In teaching, the learning process plays an important role. Teaching is the process of guiding learning activities and teaching activities are only meaningful when student learning activities occur (Slameto, 2014). Motivation in learning activities also plays a role as a cause of passion, feeling happy and eager to learn. Students who have motivation will do more learning activities, thus what will be achieved will be even better. Students will succeed well if in themselves there is a desire to learn (Ahmadi, 2016).

Hamalik (2012) explains that every human being has needs that must be met so that there is a balance in the individual human being in meeting needs. These needs will cause encouragement, both from within and from outside the individual, which is called a motive. Emphasized by Gunawan (2016) motivation is an effort that encourages students to do something. Motivation can be said as a driving force from within the subject to carry out certain 
activities in order to achieve goals. According to Purwanto (2015) motivation is the driver of a conscious effort to influence a person's behavior so that he moves his heart to act to do something so as to achieve certain results or goals.

Based on the description above, it can be concluded that motivation is a change of energy in a person's self which is characterized by the emergence of a desire to act to do something so as to achieve certain results or goals.

According to Hamalik (2012), the function of student learning motivation is 1) Encouraging students to learn, 2) determining the direction of learning, 3) selecting learning activities. For clarity, the researchers describe as follows: (1) Encouraging students to learn, meaning that guidance and counseling teachers provide motivation that functions as a driving force or motor for teaching and learning activities; (2) Determine the direction of learning, meaning towards the goals that have been outlined by the manager of teaching and learning activities to be achieved; and (3) selecting activities, determining what actions must be done to achieve the goal.

Furthermore, Djamarah (2011) explains that there are 3 (three) functions of learning motivation, a) Motivation as a driver of action, b) Motivation as a driver of action, c) Motivation as a driver of action. According to Sardiman (2011) three functions of motivation are (1) Encouraging the emergence of behavior or actions. Without motivation there will be no action. Motivation in this case is the driving force of every activity to be carried out; (2) Motivation serves as a guide. This means that motivation directs change to achieve what is desired. Thus, motivation can provide direction and activities that must be carried out in accordance with the formulation of its objectives; and (3) Motivation functions as a driver. It means to move someone's behavior. In addition, learning motivation serves as a driver of effort and achievement.

Roestiyah (2018) explains that learning motivation has the following functions (1) Motivation as a driver that encourages learning activities; (2) Intrinsic motivation is more important than extrinsic motivation; (3) Motivation in the form of praise is better than punishment; (4) Motivation is closely related to learning needs; (5) Motivation can foster optimism in learning; and (6) Motivation gives birth to achievement in learning. Purwanto (2015) said that the function of learning motivation is as follows: (1) Encouraging humans to act, so as a mover or motor that releases energy. Motivation in this case is the driving force of every activity to be carried out; (2) Determine the direction of action, namely towards the goal to be achieved. Thus, motivation can provide direction and activities that must be carried out in accordance with the formulation of its objectives; and (3) Selecting actions, namely determining what actions must be carried out that are harmonious in order to achieve the goal, by setting aside actions that are not useful for that purpose.

Based on the theoretical description above, it can be concluded that learning motivation is basically part of the general motivation given by teachers to students and students have a desire to be motivated or vice versa.

In learning, motivation is needed. Motivation is an essential condition of learning. Learning outcomes will be optimal, if there is motivation. The more precise the motivation given, the more successful the lesson will be (Hamalik, 2012). Further stated by Slameto (2014), the benefits of learning motivation provided by guidance and counseling teachers to students are: 1) Generating encouragement for students to learn, 2) Forming good study habits, 3) Helping 
students' learning difficulties, both individually and in groups. Gunawan (2016) explains that some of the benefits that can be received from learning motivation for students include: 1) Awareness of learning positions, processes, and final results; 2) Informing about the strength of the learning effort; 3) Boosting students' enthusiasm for learning; 4) Directing learning activities as an illustration, after he found out that he had not studied seriously, proved to be a lot of joking.

Furthermore, Purwanto (2015) explains that the benefits of learning motivation for students are 1) Generating and maintaining students' enthusiasm to learn until they succeed; 2) Students' learning motivation in class varies, some are indifferent, some are not paying attention, some are playing besides those who are passionate about learning; 3) Increase and make teachers aware to choose something among various roles such as advisor, facilitator, instructor, discussion partner, motivator, teacher educator. Furthermore, Djamarah (2011) states that there are three benefits of motivation that can be felt by students, 1) motivation as a driving force of action; 2) motivation as a driver of action; and 3) motivation as action guide.

Based on the description stated above, it is concluded that the benefits of learning motivation are to generate encouragement for students to learn, to form good study habits.

\section{Methods}

This research was conducted at SMA Negeri 1 Gelumbang and SMA PGRI Gelumbang. Research time is allocated in April 2020-June 2020. The design of this study describes the procedures or steps that must be taken, the time of the study, the source of the data and the conditions under which the data was collected, and the manner in which the data was collected and processed (Sukmadinata, 2015). The type of research carried out in this study is quantitative research and describes the research findings. Quantitative research is based on the philosophy of positivism which emphasizes objective phenomena and is studied quantitatively (Sugiyono, 2015). The objectivity of this research is maximized by using numbers, statistical processing, which are used to answer problems through careful measurement techniques for certain variables, so as to produce conclusions that can be generalized regardless of the context of time and situation as well as the type of data collected, especially quantitative data (Arifin, 2011). The quantitative approach in this research is to analyze the questionnaire data, which is then analyzed using SPSS For Windows. In this study, the researcher classified the independent variable (X) and the dependent variable (Y) as follows 1) Means (X1), Learning Motivation (X2), and Student Learning Outcomes (Y).

\section{Results and Discussion}

The description of research data about the influence of learning facilities and motivation on student learning outcomes in high school was taken from the collection of questionnaire data distributed to each teacher who was sampled in this study, namely in SMA Negeri 1 Gelumbang as many as 62 teachers and in SMA PGRI Gelumbang as many as 38 teachers with a total sample of 100 teachers. The population in this study were teachers who teach at SMA PGRI Gelumbang and SMA Negeri 1 Gelumbang with a total of 100 teachers consisting of 14 male teachers and 24 female teachers. Data collection techniques include (1) Questionnaire as the main instrument. The questionnaire presented varied with alternative answers 1) Always (SL), 2) Often (SR), 3) Rarely (JR), 4) Never (TP) (Sugiyono, 2015). 
The questionnaires were presented varied with alternative answers of 1) Always (SL), 2) Often (SR), 3) Rarely (JR), 4) Never (TP) given to each teacher as many as 100 teachers. Questionnaires were given to each high school teacher of 100 teachers as the researchers described in the sample above; (2) Documentation in the form of questionnaire data distributed to each high school teacher, research permits, research photos which are supporting materials in this research; and (3) Observations which are the focus of this research study in the observation activities carried out at SMA Negeri 1 Gelumbang and at SMA PGRI Gelumbang. Observational data that will be used as research support materials and other supporting data to complete the research data.

The data analysis technique in this study used simple correlation data analysis techniques and multiple regression with the help of the SPSS Windows program. The analysis phase includes: (1) descriptive analysis, (2) requirements analysis test, and (3) hypothesis testing. If the test is normal, then the results of statistical calculations can be generalized to the population. The normality test was carried out either manually or using a computer program SPSS For Windows Version 21 (Ghazali, 2013). In this study, the Kolmogorov-Smirnov test can be used to test for normality, the criterion is significant for the two-sided test. The calculation result is greater than $>0.05$, which means that it is normally distributed.

Based on the results obtained through the test of the questionnaire facility (X1), it is known that as many as 20 statement items are declared valid and have a significant value of $>5 \%$, so they can be included in further research. Furthermore, testing the validity of the learning motivation questionnaire, based on the results obtained through the validity test of the learning motivation questionnaire, it is known that as many as 20 statement items are declared valid as many as 19 statement items and have a significant value $>5 \%$, so they can be included in further research. Test the validity of the questionnaire on the performance of elementary school teachers. Based on the results obtained through testing the validity of the questionnaire on the learning outcomes of high school students, it is known that as many as 23 statement items are declared valid as many as 22 statement items and have a significant value $>5 \%$, so they can be included in further research.

Based on the results of the reliability test on each variable, it shows that the statistical value through the SPSS facility program (X1) is 0.808 , and the value for learning motivation (X2) is 0.735 , while for the value of student learning outcomes $(\mathrm{Y})$ the value is 0.717 . This shows that all variables have an alpha coefficient above 0.6 , so it can be said that all the measurement concepts of each variable from the questionnaire tested are reliable, which means that the questionnaire distributed and used in this study is a questionnaire that deserves to be included in further research.

To test the hypothesis that has been proposed or to determine whether there is an influence between variables, multiple regression analysis is used with the criteria F-count $>$ F-table. The implementation of this hypothesis test was carried out with the help of the SPSS Software For Windows Version 21 program. Hypothesis testing was used for F-calculation of the frequency distribution test at a significance level $(\alpha)$ of $5 \%$. Ho is rejected if the F-count $>$ F-table or the significance of $\rho$ is less than $\alpha$. To find out the contribution or the percentage range for the calculation of the results obtained in the analysis using the SPSS For Windows Version 21 software application.

Normality test found that the means variable (X1) is normally distributed. It is known from the results of the analysis obtained a value of $0.836>0.05$, and the learning motivation variable 
(X2) is also normally distributed. It is known from the analysis results obtained a value of $0.363>0.05$. Thus, the variables in this study are jointly normally distributed, that is, it is known that the learning outcomes of high school students (Y) obtained a value of $0.425>0.05$.

Based on the results of the multicollinearity test, the tolerance value for X1 and X2 is 0.964 > 0.10 , it can be concluded that there is no multicollinearity, and the Variance Inflation Factor (VIF) $\mathrm{X} 1$ and $\mathrm{X} 2$ values are $1.037<10$, so it can be concluded that there is no multicollinearity in this study.

The linearity test was carried out on each independent and bound variable with the criterion that the F-count value listed in the dev column. From linearity is smaller than F-table. If the results of the linearity test are like the criteria (Prayitno, 2016). The linearity test of X1 against Y partially shows that F-count $<$ F-table, which is the value in the dev path. From linearity of $0.978<0.005$. Thus it can be said that there is a significant influence of means on the learning outcomes of high school students.

The linearity test of X2 against Y partially shows that F-count $<$ F-table, which is the value in the dev path. From linearity of $0.223<0.005$. Thus it can be said that there is a significant effect of learning motivation on high school students' learning outcomes. The linearity test of $\mathrm{X} 1$ and X2 simultaneously shows that F-count < F-table, which is the value in the dev path. From linearity of $0.279<0.005$. Thus, it can be said that there is a significant influence of learning facilities and motivation on high school students' learning outcomes.

Simultaneous Multiple Linear Regression Analysis (F-Test), this test is used to determine whether the regression coefficient has a significant effect or not simultaneously (together) between the independent variables (X1 and X2) on the dependent variable (Y). If sig. > (0.05), then the regression coefficient is not significant. If Sig. $<(0.05)$, then the regression coefficient is significant. Multiple linear regression analysis is often referred to as simultaneous hypothesis testing or f-test which is shown in the table below the results of calculations using the SPSS version 21 application program

Based on the F-count, it is known that the value obtained is 6.213. Hypothesis test criteria if Fcount > F-table then Ha is accepted, and if otherwise F-count < F-table then Ha is rejected. Based on Ftable at a significant level (0.05) with $\mathrm{db}$ as the numerator of 2 (determined from the number of independent variables) and db denominator 97 (determined from the number of samples minus the independent variable minus one) or can be determined through the application of the Excel program in an empty cell type the formula = FINV $(0.05,2.97)$ obtained a number of 3.231 (Prayitno, 2010).Based on the explanation above, it is known that F-count $=6.213$ and F-table 3.231 where F-count > F-table which means Ha is accepted or it can be said that there is an influence There is a significant positive relationship between learning facilities and motivation on high school students' learning outcomes, $\mathrm{X} 1$ on $\mathrm{Y}$ contributes $0.64 \%, \mathrm{X} 2$ on $\mathrm{Y}$ contributes $0.6 \%$, and $\mathrm{X} 1$ and $\mathrm{X} 2$ on Y contributes by $11.4 \%$.

Based on the results of the first hypothesis test, the results of simple linear regression analysis based on the Summary Model output obtained an R number of 0.253 which means that the relationship between the two variables $\mathrm{X} 1$ to $\mathrm{Y}$ which shows the influence category is less strong. Because the double correlation value is between $0.200-0.399$. Thus it can be said that the means have a less strong influence on the learning outcomes of high school students. Standard Error of Estimated means measuring the variation of the predicted value. In this study the standard deviation of 2.275. The smaller the standard deviation, the better the model. 
Analysis of the coefficient of determination is used to determine the presentation of the contribution of the influence of the independent variable on the dependent variable. Based on the calculations that have been done, the coefficient of determination R Square (R2) is 0.64, which means that the means (X1) is able to influence the learning outcomes of high school students (Y) by contributing 6.4\%. The results of partial linear regression analysis (t-test) on the means variable (X1) on the learning outcomes of high school students (Y) using the SPSS version 21 program application are shown by the constant coefficient number $=2.377$ and the coefficient $\mathrm{X} 1=0.193$, so that a simple linear regression equation is obtained $\hat{\mathrm{Y}}=2.377+$ $0.193 \mathrm{X}$ or the partial regression equation between the variables $\mathrm{X} 1$ to $\mathrm{Y}$ is $\mathrm{Y}=2.377+0.193$ $\mathrm{X} 1$.

Furthermore, the equation is used to explain the effect of the means (X1) on the learning outcomes of high school students (Y). The results of the coefficient analysis obtained t-count of 2.588. hypothesis test criteria if tcount $>\mathrm{t}$-table then $\mathrm{Ha}$ is accepted while if $\mathrm{t}$-count $<\mathrm{t}$-table then $\mathrm{Ha}$ is rejected and to determine $\mathrm{t}$-table look for $\mathrm{a}=5 \%: 2=2.5 \%$ (2-sided test) with degrees of freedom $(\mathrm{df})=\mathrm{nk}$ or $\mathrm{df}=100-2=98(\mathrm{n}$ is the number of samples and $\mathrm{k}$ is the number of independent variables). With a two-tailed test (significant $=0.025$ ) the results obtained for the t-table of 2.019. based on the explanation above, $\mathrm{t}$-count $=2.588$ and $\mathrm{t}$-table $=$ 2.019 , then $\mathrm{t}$-count $>\mathrm{t}$-table which means Ho is rejected and $\mathrm{Ha}$ is accepted. Thus it can be said that partially there is a positive and significant influence between the means on the learning outcomes of high school students.

Based on the second hypothesis test, the results of simple linear regression analysis based on the Summary Model output obtained an R number of 0.244 which means that the relationship between the two variables $\mathrm{X} 2$ to $\mathrm{Y}$ which shows the influence category is less strong. Because the double correlation value is between $0.200-0.399$. Thus it can be said that between learning motivation has a less strong influence on the learning outcomes of high school students. Standard Error of Estimated means measuring the variation of the predicted value. In this study the standard deviation of 2.280. The smaller the standard deviation, the better the model.

Analysis of the coefficient of determination is used to determine the presentation of the contribution of the influence of the independent variable on the dependent variable. Based on table 4.72, it can be explained that the figure obtained by the coefficient of determination $\mathrm{R}$ Square (R2) is 0.060 , which means that learning motivation (X2) is able to influence the learning outcomes of high school students (Y) by contributing $0.6 \%$.

Based on the results of partial linear regression analysis (t-test) on the learning motivation variable (X2) on high school learning outcomes (Y) using the SPSS version 21 program application, the coefficient constant $=3.770$ and the coefficient $\mathrm{X} 2=0.237$, so that the linear regression equation is obtained. simple $=3.770+0.237 \mathrm{X}$ or the partial regression equation between the variables $\mathrm{X} 2$ to $\mathrm{Y}$ is $\mathrm{Y}=3.770+0.237 \mathrm{X} 2$. then the equation is used to explain the effect of learning motivation (X2) on high school student learning outcomes (Y). The results of the coefficient analysis obtained tcount of 2.137 hypothesis testing criteria if $t$-count $>$ $\mathrm{t}$-table then $\mathrm{Ha}$ is accepted while if tcount $<$ ttable then $\mathrm{Ha}$ is rejected and to determine $\mathrm{t}$-table is sought $\mathrm{a}=5 \%: 2=2.5 \%$ (2-sided test) with degrees of freedom $(\mathrm{df})=\mathrm{nk}$ or $\mathrm{df}=100-2=$ 98 ( $\mathrm{n}$ is the number of samples and $\mathrm{k}$ is the number of independent variables).

With two-tailed test (significant $=0.025$ ) the results obtained for the $t$-table of 2.494 . based on the explanation above, namely tcount $=3.137$ and $\mathrm{t}$-table $=2.494$, then $\mathrm{t}$-count $>\mathrm{t}$-table which means Ho is rejected and $\mathrm{Ha}$ is accepted. Thus it can be said that partially there is a positive 

outcomes.

Based on the third hypothesis test, the coefficient constant $=3.146$ and the coefficient $\mathrm{X} 1=$ 0.178 and the coefficient $\mathrm{X} 2=0.217$, so that the multiple linear regression equation $\mathrm{Y}=3.146$ $+0.178 \mathrm{X} 1+0.217 \mathrm{X} 2$ is obtained. then the equation is used to explain the effect of facilities (X1) and learning motivation (X2) on high school student learning outcomes (Y). The value of the variable coefficient $\mathrm{X} 1=0.178$ and $\mathrm{X} 2=0.217$ is positive, then the value of the $\mathrm{Y}$ variable always increases, meaning that the higher the level of facilities (X1) and learning motivation (X2), the higher the influence on high school student learning outcomes (Y).

The results of multiple linear regression analysis based on the Summary Model output obtained an $\mathrm{R}$ number of 0.337 which means that the relationship between the variables $\mathrm{X} 1$ and $\mathrm{X} 2$ (independent) on Y (dependent) which indicates the category of influence is less strong. Because the double correlation value is between 0.200-0.399. Thus it can be said that the means and motivation to learn have a less strong influence on the learning outcomes of high school students. Standard Error of Estimated means measuring the variation of the predicted value. In this study the standard deviation of 2.225, the smaller the standard deviation, the better the model.

Analysis of the coefficient of determination is used to determine the presentation of the contribution of the influence of the independent variable on the dependent variable. Based on table 4.74 it can be explained that the figure obtained by the coefficient of determination $\mathrm{R}$ Square (R2) is 0.114 , which means that the means (X1) and learning motivation (X2) are able to influence student learning outcomes $(\mathrm{Y})$ by contributing $11.4 \%$, while $88.6 \%$ is explained by factors not included in this study.

This test is used to determine whether the regression coefficient has a significant effect or not simultaneously (together) between the independent variables (X1 and X2) on the dependent variable (Y). If sig. > (0.05), then the regression coefficient is not significant. If Sig. < (0.05), then the regression coefficient is significant. Multiple linear regression analysis is often referred to as simultaneous hypothesis testing or f-test which is shown in the table below the results of calculations using the SPSS version 21 application program.

Based on the third hypothesis test using the F-test, where the F-count is known that the value obtained is 6.213. Hypothesis test criteria if F-count > F-table then Ha is accepted, and if otherwise F-count $<$ F-table then Ha is rejected. Based on Ftable at a significant level (0.05) with $\mathrm{db}$ numerator 2 (determined from the number of independent variables) and $\mathrm{db}$ denominator 97 (determined from the number of samples minus the independent variable minus one) or can be determined through the application of the Excel program in an empty cell type the formula $=$ FINV $(0.05,2.97)$ obtained a figure of 3.231 (Prayitno, 2010). Based on the explanation above, it is known that F-count $=6.213$ and F-table 3.231 where F-count $>$ F-table which means $\mathrm{Ha}$ is accepted or it can be said that there is a significant positive influence between learning facilities and motivation on high school student learning outcomes.

\section{E. Conclusion}

Based on the results of the study, it can be concluded as follows: (1) There is an influence of means on student learning outcomes in high school, and contributes $0.64 \%$ of the influence; (2) There is an influence of learning motivation on student learning outcomes in high school, 
Journal of Social Work and Science Education

Volume 2 (1) 2021

E-ISSN: 2723-6919 P-ISSN:2746-0827

and contributes $0.60 \%$; (3) There is an effect of learning facilities and motivation together either simultaneously or partially on student learning outcomes in high school, and contributes $11.4 \%$ of the influence; (4) The first hypothesis test obtained values, namely t-count $=2.588$ and $\mathrm{t}$-table $=2.019 ;(5)$ The second hypothesis test is obtained by the value of $\mathrm{t}$-count $=3.137$ and t-table $=2.494$; and (6) The third hypothesis test obtained values, namely F-count $=6.213$ and F-table 3.231.

\section{References}

Ahmadi, A. (2016). Studi Minat dan Motivasi Belajar Siswa [Study of Students' Interests and Learning Motivation]. Jakarta: Rineka Cipta.

Arifin. Z. (2011). Penelitian Pendidikan; Metode dan Paradigma Baru [Educational Research; New Methods and Paradigms]. Bandung: Remaja Rosdakarya.

Astuti, R. W., Fitria, H., \& Rohana, R. (2020). The Influence of Leadership Styles and Work Motivation on Teacher's Performance. Journal of Social Work and Science Education, 1(2), 105-114. https://doi.org/10.52690/jswse.v1i2.33

Aunurrahman. (2014). Belajar dan Pembelajaran [Learning and Instruction]. Jakarta: Rajawali Pers.

Darmiati, D., Kristiawan, M., \& Rohana, R. (2020). The Influence of School Leadership and Work Motivation toward Teacher's Discipline. Journal of Social Work and Science Education, 1(1), 32-44. https://doi.org/10.52690/jswse.v1i1.8

Daryanto. (2017). Administrasi dan Manajemen Sekolah [School Administration and Management]. Jakarta: Rineka Cipta.

Djamarah, S. B. (2011). Psikologi Belajar [Learning Psychology]. Jakarta: Rineka Cipta.

Ghazali, I. (2013). Aplikasi Analisis Multivariat dengan Program SPSS [Multivariate Analysis Application with SPSS Program]. Semarang: Badan Penerbit Universitas Diponegoro.

Gunawan, A. (2016). Administrasi Sekolah: Administrasi Pendidikan Mikro [School Administration: Micro Education Administration]. Jakarta: Rineka Cipta.

Hamalik, O. (2012). Motivasi Belajar-Mengajar [Learning and Teaching Motivation]. Jakarta: Raja Graffindo Persada.

Haryati, M. (2011). Model \& Teknik Penilaian Pada Tingkat Satuan Pendidikan [Assessment Models \& Techniques at the Education Unit Level]. Jakarta: Gaung Perkasa Press.

Hasibuan, J. J. (2010). Proses Belajar Mengajar [Instructional Process]. Bandung: Remaja Rosdakarya.

Ibrahim, I., Fitria, H., \& Puspita, Y. (2020). The Effect of Work Discipline and Teacher's Motivation on Teacher's Performance. Journal of Social Work and Science Education, 1(2), 140-145. https://doi.org/10.52690/jswse.v1i2.41 
Journal of Social Work and Science Education

Volume 2 (1) 2021

E-ISSN: 2723-6919 P-ISSN:2746-0827

Karwono. (2017). Belajar dan Pembelajaran Serta Pemanfaatan Sumber Belajar [Learning and Instruction, Utilization of Learning Resources]. Jakarta: Rajawali Pers.

Law Number 19 of 2005 concerning National Education Standards

Maryati, S., Ahmad, S., \& Eddy, S. (2021). Management for Improving the Quality of Student Learning in Primary Schools. Journal of Social Work and Science Education, 1(3), 257265. https://doi.org/10.52690/jswse.v1i3.113

Matin., \& Nurhattati, F. (2016). Manajemen Sarana dan Prasarana Pendidikan (Konsep dan Aplikasinya) [Management of Educational Facilities and Infrastructure (Concepts and Applications)]. Jakarta: Dian Rakyat.

Musfiqon., \& Andiek, W. (2016). Pengembangan dan Media Sumber Pembelajaran [Learning Resource Development and Media]. Jakarta: Raja Graffindo Persada.

Prayitno, D. (2010). Paham Analisa Statistik Data dengan SPSS [Understand Statistical Analysis of Data with SPSS]. Yogyakarta: Mediakom.

Pribadi, B. A. (2015). Media Teknologi dalam Pembelajaran [Media Technology in Learning]. Jakarta: Dian Rakyat.

Purwanto. (2015). Motivasi dan Belajar Secara Efektif [Motivate and Learn Effectively]. Jakarta: Raja Graffindo Persada

Roestiyah, N. K. (2018). Strategi Belajar Mengajar [Instructional Strategy]. Jakarta: Rineka Cipta.

Sanjaya, W. (2010). Belajar dan Pembelajaran [Learning and Instruction]. Jakarta: Raja Graffindo Persada.

Slameto. (2014). Belajar \& Faktor-Faktor yang Mempengaruhinya [Learning \& Factors Affecting It]. Jakarta: Rineka Cipta.

Sardiman, A. S. (2011). Interaksi dan Motivasi Belajar Mengajar (Pedoman Bagi Guru dan Calon Guru) [Teaching and Learning Interaction and Motivation (Guidelines for Teachers and Prospective Teachers)]. Jakarta: Rajawali Pres.

Sugiyono. (2015). Metode Penelitian Pendidikan, Pendekatan Kuantitatif, Kualitatif dan R \& $D$ [Educational Research Methods, Quantitative, Qualitative and R\&D Approaches]. Bandung: Alfabeta.

Sukmadinata, N. S. (2015). Metode Penelitian Pendidikan [Educational Research Methods]. Bandung: Remaja Rosdakarya.

Suryabrata. (2014). Psikologi Belajar [Learning Psychology]. Jakarta: Rajawali Pers.

Syah, M. (2011). Motivasi Belajar [Learning Motivation]. Jakarta: Rineka Cipta. 
Journal of Social Work and Science Education

Volume 2 (1) 2021

E-ISSN : 2723-6919 P-ISSN:2746-0827

Triwiyanto, T. (2015). Pengantar Pendidikan [Introduction to Education]. Jakarta: Bumi Aksara.

Yamin, M. (2012). Manajemen Mutu Kurikulum Pendidikan [Education Curriculum Quality Management]. Jakarta: Rajawali Pers.

Yunita, E., Arafat, Y., \& Mulyadi, M. (2020). The Function of Class Teacher Educational Management in Improving Student's Learning Outcomes. Journal of Social Work and Science Education, 1(2), 168-180. https://doi.org/10.52690/jswse.v1i2.46 